\title{
The Development of Lifelong Learning Trends Scale
}

\author{
(LLLTS) ${ }^{*}$
}

\author{
Duygu GÜR ERDOĞAN**
}

\author{
Zeki ARSAL ${ }^{* * *}$
}

\begin{abstract}
The main aim of this study is to develop a a valid and reliable scale to measure lifelong learning trends. For this purpose, general review of the literature was made and scale item pool was created. The scale was carried out with a total of 1644 students who studied in Abant Izzet Baysal and Sakarya University in the Faculty of Education volunteered to participate in the study. Exploratory factor analysis was carried out to demonstrate structure scale of the factor. At the end of the research results, it was found that the scale had a 17-item and two-factor structure. The factors determined according to the substances they contain were called as "willingness to learn" and "openness to improvement". Total exposition of these two factors is $43.44 \%$. Construct validity of the scale was tested by confirmatory factor analysis. The criterion validity of the scale was also found to be .71 . Calculated for the reliability of the scale, Cronbach's alpha internal consistency coefficient was found to be .86 while $\omega$ value was calculated as .89 . For the scale stability, test-retest reliability coefficient was found to be .76 . The findings show that the scale has adequate validity and reliability to measure lifelong learning trends.
\end{abstract}

Keywords: Lifelong Learning, Trends, Reliability, Validity, Scale.

\section{Yaşam Boyu Öğrenme Eğilim Ölçeği (YBÖEÖ)'nin}

\section{Geliştirilmesi}

Öz

Bu çalışmanın temel amacı yaşam boyu öğrenme eğilimini ölçmek amacıyla geçerli ve güvenilir bir ölçek geliştirmektir. Bu amaç doğrultusunda genel literatür taraması yapılarak ölçek madde havuzu oluşturulmuştur. Ölçeğin geliştirme çalışmalarında örneklemi Abant İzzet Baysal Üniversitesi ve Sakarya Üniversitesi Eğitim Fakültesinde okuyan ve çalışmaya gönüllü olarak katılan 1644 öğrenci oluşturmaktadır. Ölçeğin faktör yapısını ortaya koymak için açımlayıcı faktör analizi yapılmıştır. Yapılan analizler sonucunda ölçeğin 17 maddelik iki faktörlü bir yapıda olduğu bulunmuştur. Belirlenen faktörler içerdikleri maddelere göre "öğrenmeye isteklilik" ve "gelişime açıklık" olarak isimlendirilmiştir. Bu iki faktörün toplam açıklayıcılığı \% 43,44”'tür. Ölçeğin yapı geçerliği doğrulayıcı faktör analizi ile test edilmiştir. Ayrıca ölçeğin ölçüt ölçek geçerliği .71 olarak bulunmuştur. Ölçeğin güvenirliğine ilişkin olarak hesaplanan Cronbach's alfa iç tutarlılık katsayı .86 ve $\omega$ değeri .89 olarak hesaplanmıştır. Ölçeğin kararlılığına ilişkin test tekrar test güvenirlik katsayısı .76 olarak

\footnotetext{
* This study is made of doctoral thesis

** Assist. Prof. Dr., Sakarya University, Education Faculty, dgur@sakarya.edu.tr

${ }^{* * *}$ Assoc. Prof. Dr., Abant İzzet Baysal University, Education Faculty, arsal_z@ibu.edu.tr
} 
bulunmuştur. Bulgular ölçeğin yaşam boyu öğrenme eğilimini ölçmek için yeterli düzeyde geçerlik ve güvenirliğe sahip olduğunu göstermektedir.

Anahtar Kelimeler: Yaşam boyu öğrenme, Eğilim, Geçerlik, Güvenirlik.

\section{INTRODUCTION}

Dewey (1993) refers to the importance of trends in filling the gap between asking for something and doing it. According to him, knowing only application routes is not enough to achieve the request. Therefore, Dewey (1993) states that a request should be for application and that this request is a personal trend status. A trend borns from a desire or motivation which provides the necessary energy for action (Perkins, Jay andTishman 1993a, 1993b; Tishman, Jay and Perkins 1993; RitchhartandPerkins 2000; cited in: Crick and $\mathrm{Yu}, 2008)$. Individuals' tendency and willingness to something shows their trends. Skills reflects cognitive dimension of individuals while trends reflects their affective dimension.

Lifelong learning is described as a continuous process and a multi purpose of learning activities taken with the objectives of improving one's knowledge, skills and competence (OECD, 2001). Lifelong learning contributes to the economic adaptability of societies, "personal development and fulfillment" of individuals, and "social inclusiveness and democratic understanding (Aspin and Chapman, 2000). Although its such contribution, the concept of lifelong learning remains unclear although there are continuous research and study (Confessor, 1992; Houle, 1961; Johnstone and Rivera, 1965; cited in Derrcik, 2003; Tough, 1979) in this area to explain lifelong learning trend and to understand the key factors and behaviors associated with the individual's lifelong learning trend.

Lifelong learning is a natural tendency to continue learning, growth and development and this trend is a process which may occur with the elimination of negative, insecure thoughts and belief systems, and the discovery of learning trends (McCombs, 1991). However, the measurement of lifelong learning trends is complex because it varies according to the competent person's purpose (teachers, doctors, students etc.) (Derrick, 2003; Crick and Yu, 2008). Despite of this difficulty, some researchers have tried to measure it. For example; Kirby, Knapper, Lamon, and Egnatoff (2010) developed a 14-item scale (designated the KirbyLLS) to assess university and college students of lifelong learning, while Coskun and Demirel (2010) conducted a study to develop a scale to measure lifelong learning. However, very few studies have been done which explore a university student's lifelong learning tendencies, especially on pre-service teachers. Whereas, some trainings on lifelong learning for teachers and their trainers in order to adapt to changes in the education system in the information society (MEB, 2006) and and teachers should be trained in this direction. The purpose of the measurement and evaluation of lifelong learning trends is to encourage personal change in individuals through critical/self-reflection, to invite them to take responsibility and use the information for their own learning process, and also to create data for programmers, learners' coaches and organizational leaders on improving ways for preservice learning (Crick and $\mathrm{Yu}$, 2008). Therefore, the main aim of this study is to develop a scale to measure lifelong learning trends of preservice teachers. Because nearly impossible to provide pre-service teachers with all of the pedagogical knowledge they will need to sustain them throughout their professional life, it is important to prepare future teachers for careers as lifelong learners.

\section{METHOD}

\subsection{Procedure}

The scale development phases are consist of determining the scale items; creation, prepara- 
tion, implementation of the pilot scale; and the validity and reliability studies. For determining the scale item, the relevant literature review was firstly made and an item pool was created from underlying structure on the subject. The items in the created item pool were examined by 7 experts (a Guidance and Counseling expert, an Educational Administration and Supervision expert, three Educational Curriculum and Instruction experts and two Measurement and Evaluation experts). In multidimensional measurement tools consisting of multiple subscale, it must be evaluated by experts whether the written items are about the factor in which they are expected to be included for the aim of determining the different factors of the structure to be measured (DeVellis, 2003). It must be the common definitions between experts on the subject and the individuals developing a measurement tool because determining the scope on an issue requires a judgment (Tavşancıl, 2006). Removed some items as a result of this review, a 5-point Likert-type pre-trial scale was formed with the remaining 49 items in the pool. On the purpose of providing the suitability of the sample forming the basis of the study, this pretest scale was performed on group of $300 \mathrm{stu}-$ dents who voluntarily participated in the study and are 3rd and 4th grade students of Abant Izzet Baysal University Faculty of Education for validity and reliability studies. Before analyzing the data obtained, missing values in the study data were examined by performing data cleansing after observing missing values and left-right skewed data through frequency tables (Meyers, GamstandGuarimo, 2006: 44; Tabachnickand Fidel, 2007: 62). It is seen that there is not more than $3 \%$ missing value in any of the tables belonging to the items. Moreover being determined the noising values in the data set, it has been restored and reorganize the data set. Considering that extreme values which has the values outside the usual value or excess value can distort the statistical results, raw scores were converted to standard $\mathrm{Z}$ score and the scales outside the range of $-3+3$ were excluded from the study. Because when the normal dis- tribution is considered, $99 \%$ of the data will take place in the distance \pm 3 standard deviations from the average (Çokluk, Şekercioğlu and Büyüköztürk, 2012). After this process, the necessary analyses were made through the remaining 271 data.

\section{RESULTS}

Exploratory factor analysis (EFA) and confirmatory factor analysis (CFA) methods were used in order to determine the construct validity LLLTS. Before EFA was performed, it was examined whether the data set was appropriate for factor analysis. For factor analysis studies, Tabachnickand Fidel (2001) emphasize that sample size of approximate 150 may be sufficient while Kline (1994) states that sample size of approximate 200 is sufficient (Cited in: Çokluk et al, 2012). Based on this expression, it can be said that the number of participants in the study is adequate for factor analysis because the data set of 271 persons meet acceptable levels of factor analysis.

\subsection{Exploratory Factor Analysis}

First of all Kaiser-Meyer-Olkin (KMO) testing sample adequacy was examined in order to be made exploratory factor analysis through the data obtained from 271 students participated in the preliminary studies. KMO value was found to be 0.89 . According to Kaiser (1974), KMO values above 0.5 are acceptable values. It is stated that $\mathrm{KMO}$ value must be higher than 0.60, and Spehericity and Barlett test must be meaningful for factor analysis (Büyüköztürk, 2007). Secondly, Bartlett's Spehericity test was analyzed $(\chi 2=1405.164, \mathrm{p}=.000)$ and it was determined that the obtained data were suitable for factor analysis (Green and Salkind, 2005). For the determination of the items to be included in the scale, according to Büyüköztürk (2007), it is considered adequate that the Eigen values of the factors should be 1 and over, the load values of the items be at least 0.30 , and item total correlation value be 0.30 and over. Moreover, it was paid attention 
that the items would be in the same factor, and if there are the factors in two factors then at least 0.10 differences should be between them. In the first factor analysis, 32 items in the 49 item-trial form were removed from the scale because their factor loadings were below 0.30, they take place in multiple factors and the differences between the factors were less than 0.10 . In the second factor analysis, primarily in the principal component analysis, 25 degrees varimax rotation was carried out in the way that the Eigen values of 17 itemswould be over 1. It was found that the scale obtained as the result of these processes had a two-factor structure. The number of the scale factor can be seen more clearly in the slope angle chart derived from the exploratory factor analysis.

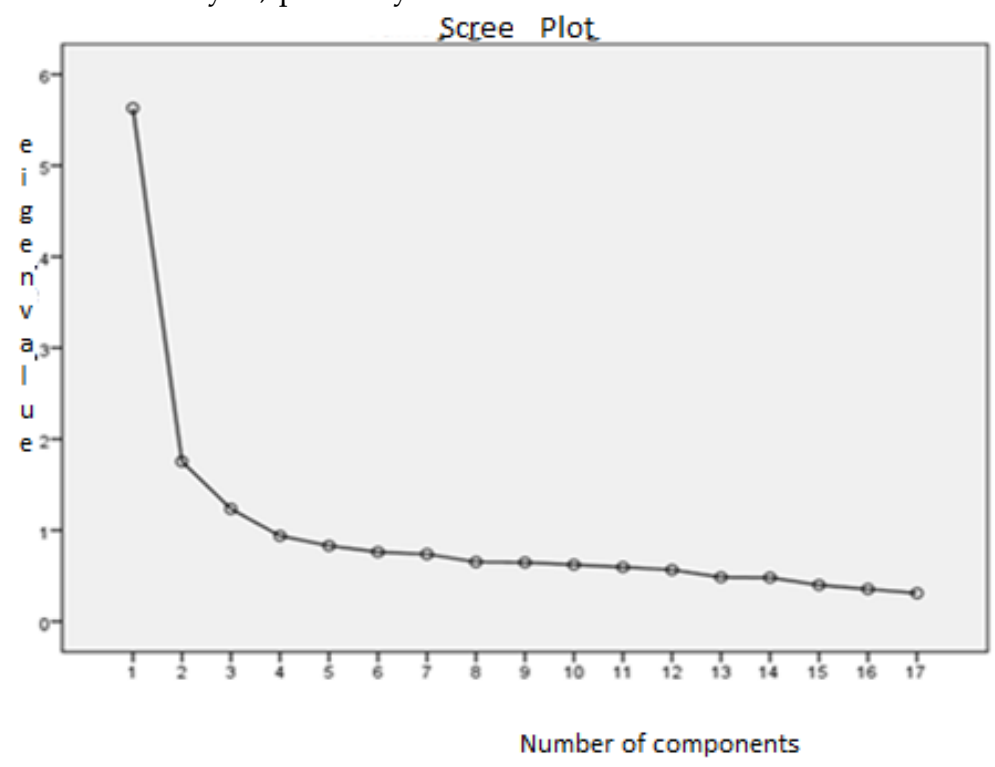

Figure 1. The slope angle chart of exploratory factor analysis

When examined the graphic, it can also been seen a two-factor structure. It was found at the end of exploratory factor analysis that the lowest factor load is 0.40 , and that the Eigen value of the scale on the factors' level is 5.630 for first factor and 1.755 for second factor. The first 11 items included in the scale at the end of exploratory factor analysis compose the first factor. This factor called as willingness to learn explains $24.12 \%$ of the total variation. The internal consistency coefficient of this factor is 0.82 . Other six items included in the scale compose the second factor. This factor called as willingness to improvement explains $19.31 \%$ of the total variation. The internal consistency coefficient of this factor is 0.82 . When all the 17 items are taken into consideration, they explains $43.44 \%$ of the total variation. When it is thought that variation rates changing between $40 \%$ and $60 \%$ in factor analysis are accepted as ideal (Tavşanc1l, 2006), it can be said that the amount of variance obtained in this study can be described as satisfactory. The internal consistency coefficient of the scale is found 0.86 . 
Table 1. Item analysis of LLLTS and its t-test results for the differences between $27 \%$ top and bottom groups

\begin{tabular}{ccc}
\hline Item Total Correlation $^{1}$ & $\mathrm{t}($ bottom\%27-top\%27) & Internal Consistency Factor \\
\hline 0.42 & $-6.62^{*}$ & \\
0.37 & $-5.34^{*}$ & \\
0.55 & $-8.39^{*}$ & \\
0.37 & $-7.75^{*}$ & \\
0.52 & $-8.91^{*}$ & \\
0.56 & $-9.74^{*}$ & \\
0.49 & $-9.09^{*}$ & \\
0.53 & $-9.15^{*}$ & \\
0.52 & $-7.81^{*}$ & \\
0.46 & $-8.59^{*}$ & \\
0.54 & $-9.09^{*}$ & \\
\hline 0.37 & $-6.52^{*}$ & \\
0.45 & $-7.43^{*}$ & \\
0.51 & $-7.74^{*}$ & \\
0.58 & $-10.50^{*}$ & \\
0.64 & $-11.89^{*}$ & \\
0.53 & $-9.70^{*}$ & \\
\hline
\end{tabular}

All the reliability coefficient of the scale

0.86

${ }^{1} \mathrm{n}=271{ }^{2} \mathrm{n} 1-\mathrm{n} 2=73{ }^{*} \mathrm{p}<0.001$

All items in the scale were analyzed as a whole for item-total correlation and it was seen that item-total correlations were received values between 0.37 and 0.64 . As the result of the $27 \%$ top and bottom group comparisons, it was found that $t$ values for the differences between the average of the scores they have received from LLLTS are between $5.34(\mathrm{p}<0.001)$ and 11.89 ( $p<0.001)$. Accordingly, it can be said that discrimination power of the scale items are sufficient.

Table 2. The results of exploratory factor analysis

\begin{tabular}{|c|c|c|c|}
\hline & \multirow{2}{*}{ Item Number } & \multicolumn{2}{|c|}{ After rotating Load Value } \\
\hline & & Factor-1 & Factor-2 \\
\hline \multirow{11}{*}{  } & M1 & 0.55 & \\
\hline & M3 & 0.44 & \\
\hline & M4 & 0.63 & \\
\hline & M5 & 0.40 & \\
\hline & M10 & 0.67 & \\
\hline & M16 & 0.62 & \\
\hline & M18 & 0.62 & \\
\hline & M19 & 0.67 & \\
\hline & M23 & 0.65 & \\
\hline & M25 & 0.55 & \\
\hline & M28 & 0.58 & \\
\hline
\end{tabular}




\begin{tabular}{|c|c|c|c|}
\hline \multirow{6}{*}{ 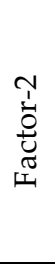 } & M39 & & 0.67 \\
\hline & M41 & & 0.72 \\
\hline & M44 & & 0.59 \\
\hline & M45 & & 0.73 \\
\hline & M46 & & 0.77 \\
\hline & M47 & & 0.72 \\
\hline \multicolumn{2}{|c|}{ Eigenvalues } & 5.630 & 1.755 \\
\hline \multicolumn{2}{|c|}{ Variance Percentage } & \% 24.12 & $\% 19.31$ \\
\hline
\end{tabular}

When examined Table 3-2, it is seen that the factor loading values for the scale items vary between 0.40 and 0.67 for the first factor, while it changes between 0.59 and 0.77 for the second factor.

\subsection{Confirmatory Factor Analysis}

The fit indexesof the model derived from the confirmatory factor analysis (CFA) which were performed for the construct validity of the scale on the data collected from 1123 faculty of education students were examined, and the results of the confirmatory factor analysis of LLLTS were given in the Figure2.

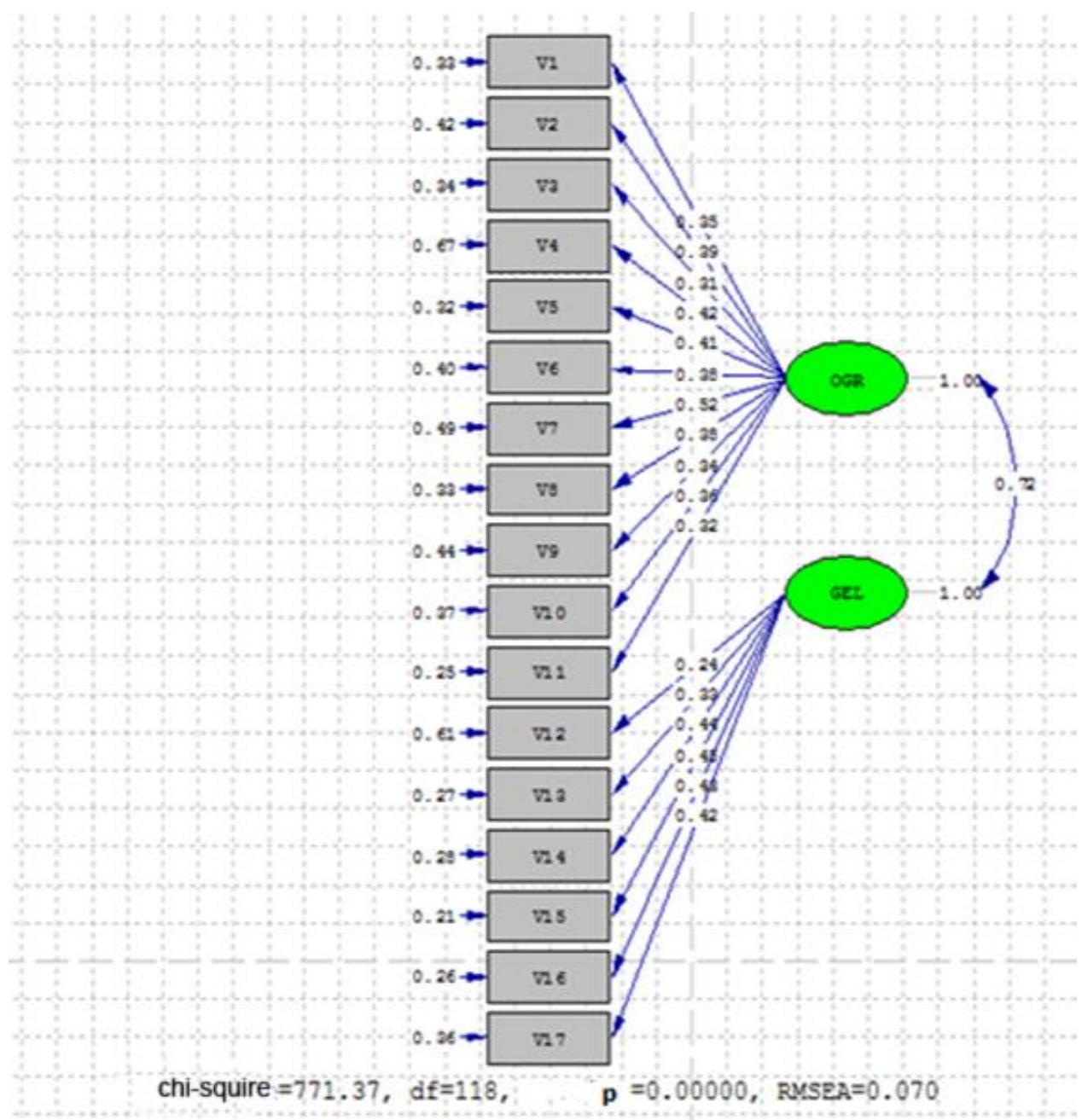

Figure 2. CFA Model of Lifelong Learning Trends Scale 
For the fit indices of the scale, it was found that $\chi 2$ value is significant ( $p<0.05)$, RMSEA $=0.07$, $\mathrm{RMR}=0.02$ ， GFI $=0.93$, AGFI $=0.90, \quad \mathrm{NFI}=0.93$, $\mathrm{NNFI}=0.93, \mathrm{CFI}=0.94$. Generally speaking for the analysis results, it was seen that $\chi^{2}$ is below 0.08 significant RMSEA value, RMS value is below 0.08, GFI, NFI AGF, NNF and CFU values are above 0.90 . Based on these results, it can be said that the scale demonstrates proficiency in measuring and the two-factor structure occurring as the results of exploratory factor is verified.

\subsection{Criterion-related Validity}

For criterion validity of lifelong learning trends scale, two scales on lifelong learning trends in Turkish literature were examined, and, in terms of sampling adequacy, teachers' lifelong learning trends scale developed by Yaman (2014) was used. The scale consists of 29 items and one factor. The reliability coefficient of the scale was calculated as 89 . The LLLTS desired to be developed and teachers' lifelong learning trends scale developed by Yaman were applied to the students $(n=250)$ who are studying in the faculty of education. A positive correlation (.71) was found between the scales $(p<0.01)$.

\section{DISCUSSION}

In this study, it was intended to develop a measurement tool which will allow to measure lifelong learning trends of teachers and preservice teachers as valid and reliable. For this purpose, the item pool created as a result of the literature review was submitted to 7 experts for content and face validity, and 49-item scale pretreatment was prepared. EFA and CFA were been applied for LLLTS's construct validity. As the result of EFA, the structure which is 17-item, two-structure and explains $43.44 \%$ of the total variance was obtained. CFA was per- formed in order to determine whether this twofactor structure gives adequate fit indices, and to obtain additional evidence for LLLTS's construct validity. The findings obtained from the CFA showed that the fit indices of the twofactor structure for LLLTS were adequate. The LLLTS desired to be developed and teachers' lifelong learning trends scale developed by Yaman were applied to the students $(n=250)$ who are studying in the faculty of education, and a positive correlation (.71) was found between the scales $(\mathrm{p}<0.01)$. The findings obtained from the correlation analysis point out that criterion-related validity of the scale was ensured. The reliability of LLLTS was examined through internal consistency, $\omega$ and testretest methods. Cronbach's alpha internal consistency coefficient was calculated as .86 while $\omega$ value was found to be 89 . Test-retest reliability coefficient for the determination of the scale was found to be .76. Considering that the scales of which reliability coefficient is .70 and over (Anastasi, 1982; Muijs, 2004; Sipahi, YurtkoruandÇinko, 2010; Stangor, 2010; cited in: İlhanandÇetin, 2013), internal consistency, $\omega$ and test-retest reliability coefficients can be regarded as evidence for scale reliability. In the study, the statistics conducted to examine the psychometric properties of LLLTS shows that the scale has a valid and reliable structure. This developed scale can be administered in studies aiming to determine from which variables lifelong learning tendencies of students studying in faculties of education and teachers are affected. In the development of this measurement tool that the sample group composes of preservice teachers can limit the study. In the future studies, the psychometric properties of the scale can be examined by selecting teachers and other occupations for sample group. 


\section{References}

Aspin, D. and Chapman, J. (2000). Lifelong Learning: Concepts and Conceptions. International Journal of Lifelong Education, 19, 2-19.

Büyüköztürk, Ş. (2007). Sosyal Bilimler için Veri Analizi El Kitabı: İstatistik, Araştırma Deseni, Spss Uygulamaları ve Yorum. Ankara: Pegem Yayınları.

Crick, R. D. and Yu, G. (2008). Assessing Learning Dispositions: Is the Effective Lifelong Learning Inventory Valid and Reliable as a Measurement Tool?.Educational Research, 50 (4), 387-402.

Çokluk, Ö., Şekercioğlu, G.and Büyüköztürk, Ş. (2012). Sosyal Bilimler için Çok Değişkenli Istatistik: SPSS ve Lisrel Uygulamaları. Ankara: Pegem Yayncilı.

Derrick, M. G. (2003). Creating Environments Conducive for Lifelong Learning, New Directions for Adult and Continuing Education, 100 (Winter).

DeVellis, R. F. (2003). Scale Development: Theory and Applications. (2nd edt). Newbury Park, CA: Sage Publications.

Green, S. B. and Salkind, N. J. (2008). Usingspss for Windows and Macintosh Analyzing and Understanding Data (5. Bask1). New Jersey: Upper Saddle River.

İlhan, M. and Çetin, B. (2013). Ortaokul Öğrencilerinin Matematik Odaklı Akademik Risk Alma Davranışları: Bir Ölçek Geliştirme Çalışması. E-International Journal of Educational Research, 4(2), pp. 128.

Kirby, J. R., Knapper, C., Lamon, P. and Egnatoff, W. J. (2010). Development of a Scale to Measure Lifelong Learning. International Journal of LifelongEducation, 29, 291-302.

McCombs, B. L. (1991). Motivation and Lifelong Learning. Educational Psychologist, 26 (2), 117-127.

MEB (2006) Meslek Dersleri Öğretmen Eğitimi Politika ve Strateji Raporu, Millî Eğitim Bakanlığı Mesleki ve Teknik Eğitimin Modernizasyonu Projesi - MTEM, Ankara

Meyers, L. S., Gamst, G. and Guarimo, A. J. (2006). Applied Multivariate Research. Design and Interpretation. Londra: Sage Pub.

Tabachnick, B. G. and Fidell, L. S. (2007). Using Multivariate Statistics (5. Baskı). Boston: Allyn and Bacon

Tavşancıl, E. (2006). Tutumların Ölçülmesi ve SPSS ile Veri Analizi. Ankara: Nobel yayınc1lı

The Organisation for Economic Cooperation and Development. (2001). Lifelong Learning for All. Paris: OECD.

Tough, A. (1979). The Adult's Learning Project. San Diego: University Associates.

Yaman, F. (2014). Öğretmenlerin Yaşamboyu Öğrenme Ĕ̆gilimlerinin Incelenmesi (Diyarbakır Ili Örneği). Yüksek Lisans Tezi, Dicle Üniversitesi Eğitim Bilimleri Enstitüsü, Diyarbakır. 


\begin{tabular}{|c|c|c|c|c|c|}
\hline YAŞAM BOYU ÖĞRENME EĞİLIMLERİ ÖLÇEĞİ & 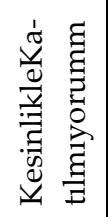 & 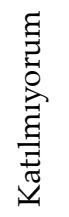 &  & 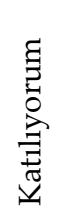 & 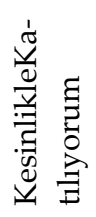 \\
\hline $\begin{array}{l}\text { 1. Kendi yeterliliklerime uygun öğrenme hedefleri belirle- } \\
\text { rim }\end{array}$ & & & & & \\
\hline 2. Öğrenme için gerekli kaynakları önceden hazırlarım & & & & & \\
\hline $\begin{array}{l}\text { 3. Öğrenme konusuna uygun öğrenme strateji kullanmanın } \\
\text { gereğine inanırım }\end{array}$ & & & & & \\
\hline $\begin{array}{l}\text { 4. Öğrenme sürecinde zamanı iyi değerlendirmek için ça- } \\
\text { lışma planı yaparım }\end{array}$ & & & & & \\
\hline $\begin{array}{l}\text { 5. Yeni bir bilgi ile karşılaştığımda öğrenebileceğim konu- } \\
\text { sunda kendime güvenirim }\end{array}$ & & & & & \\
\hline $\begin{array}{l}\text { 6. Öğrenme sürecinde kendi kendimi güdülemeyi tercih } \\
\text { ederim }\end{array}$ & & & & & \\
\hline $\begin{array}{l}\text { 7. Öğrenme konuları zor olsa bile öğrenmeye çalışmaktan } \\
\text { vazgeçmem }\end{array}$ & & & & & \\
\hline 8. Yeni şeyler öğrenmekten zevk alırım & & & & & \\
\hline $\begin{array}{l}\text { 9. Öğrenmede sürecinde ihtiyaç duyduğumda yardım } \\
\text { istemekten çekinmem. }\end{array}$ & & & & & \\
\hline $\begin{array}{l}\text { 10. Bir konuyu öğrenmenin kendi sorumluluğum olduğuna } \\
\text { inanırım }\end{array}$ & & & & & \\
\hline $\begin{array}{l}\text { 11. Yeni şeyler öğrenmenin kendimi geliştirmeme katkı } \\
\text { sağladığını düşünürüm }\end{array}$ & & & & & \\
\hline $\begin{array}{l}\text { 12. İnternetin farklı kültürleri tanımamı sağladığını } \\
\text { düşünürüm. }\end{array}$ & & & & & \\
\hline $\begin{array}{l}\text { 13. Kişisel ya da mesleki gelişimim için gerekli farklı } \\
\text { alanlardaki bilgi ve becerilerle ilgili eğitim almayı isterim }\end{array}$ & & & & & \\
\hline $\begin{array}{l}\text { 14. Bilgi ve teknolojilerdeki hızlı değişmelerden dolayı } \\
\text { bilgilerimi yenilemek için sürekli öğrenmeye ihtiyaç } \\
\text { duyarım }\end{array}$ & & & & & \\
\hline $\begin{array}{l}\text { 15. Mesleğimde karşılaşabileceğim problemleri çözmek için } \\
\text { çaba sarfederim }\end{array}$ & & & & & \\
\hline $\begin{array}{l}\text { 16. Mesleki yetersizliklerimi gidermek için eğitim alma } \\
\text { yolları ararım. }\end{array}$ & & & & & \\
\hline 17. Mesleki kariyerde ilerlemeye önem veririm & & & & & \\
\hline
\end{tabular}

